\title{
Changes in protein synthesis and phosphorylation patterns during bovine oocyte maturation in vitro
}

\author{
P. M. M. Kastrop, M. M. Bevers, O. H. J. Destrée* and Th. A. M. Kruip \\ Department of Herd Health and Reproduction, Faculty of Veterinary Medicine, University of \\ Utrecht, Yalelaan 7, 3584 CL Utrecht, The Netherlands; and ${ }^{*}$ Hubrecht Laboratory, The \\ Netherlands Institute for Developmental Biology, Uppsalalaan 8, 3584 CT Utrecht, The Netherlands
}

\begin{abstract}
Summary. Sequential protein synthesis and protein phosphorylation patterns were generated by radiolabelling bovine cumulus-oocyte complexes after various periods of culture with $\left[{ }^{35} \mathrm{~S}\right]$ methionine and $\left[{ }^{32} \mathrm{P}\right]$ orthophosphate respectively. The radiolabelled oocytes were assessed for their nuclear status and used individually for gel electrophoresis. Marked changes in the protein synthesis patterns were observed exclusively after germinal vesicle breakdown (GVBD), whereas oocytes which remained in the germinal vesicle stage showed a consistent protein synthesis pattern. The changes were observed after 8 and $16 \mathrm{~h}$ of culture, shortly after GVBD and before first polar body extrusion. From $3 \mathrm{~h}$ of culture, dominant phosphoprotein bands with apparent molecular weights of 24000 and two between 50000 and 60000 were observed. The latter bands displayed slight molecular weight changes, which were not closely time related. After GVBD, the phosphoprotein band with $M_{\mathrm{r}} 19000$ was no longer observed. This study demonstrates that specific changes in protein synthesis and protein phosphorylation are programmed during bovine oocyte maturation.
\end{abstract}

Keywords: cow; oocyte; maturation; protein synthesis; protein phosphorylation

\section{Introduction}

Mammalian oocytes are arrested at the diplotene stage of prophase I until just before ovulation. Resumption of meiosis can be induced by the transfer of oocytes from their ovarian follicles into a suitable culture medium (Pincus \& Enzmann, 1935; Edward, 1965). In the ensuing period of culture, oocytes undergo nuclear progression from diplotene to metaphase II and the change is characterized by dissolution of the nuclear membrane (Germinal Vesicle Breakdown) and extrusion of the first polar body. However, mature oocytes have not only undergone nuclear, but also cytoplasmic, changes necessary for fertilization and subsequent embryonic development (Moor \& Trounson, 1977). Structural rearrangements of organelles (Szöllösi, 1972; Cran et al., 1980; Cran, 1985) and major changes in protein synthesis patterns (Golbus \& Stein, 1976; Schultz \& Wassarman, 1977; McGaughey \& Van Blerkom, 1977; Warnes et al., 1977) take place during cytoplasmic maturation and have been described for several mammalian species.

So far, only structural changes have been described (Fleming \& Saacke, 1972; Kruip et al., 1983; Hyttel et al., 1986) for bovine oocytes. The present study examines protein synthesis and protein phosphorylation patterns during maturation of bovine oocytes in vitro.

\section{Materials and Methods}

Collection and culture of cumulus-oocyte complexes. Bovine ovaries, obtained at a local slaughterhouse, were rinsed and collected in phosphate-buffered saline (PBS; Dulbecco \& Vogt, 1954) at $30^{\circ} \mathrm{C}$ and transported to the laboratory 
within $1 \mathrm{~h}$ after slaughter. Antral follicles, between 4 and $8 \mathrm{~mm}$ in diameter, were aspirated and cumulus-oocyte complexes were recovered from the follicular fluid aspirates after sedimentation for 15 min. Subsequently, the cumulus-oocyte complexes were washed in PBS, supplemented with $4 \mathrm{mg}$ bovine serum albumin $/ \mathrm{ml}, 0 \cdot 36 \mathrm{~mm}$ pyruvate, $23.8 \mathrm{~mm}$-lactate and $5.5 \mathrm{~mm}$-glucose (Medium A), and classified under a stereomicroscope (magnification $\times 50$ ) according to De Loos et al. (1989). Only intact cumulus-oocyte complexes with a compact and multilayered cumulus investment were used in this study, since no differences in the protein synthesis patterns of these oocytes were observed in a previous study (Kastrop et al., 1990). The selection procedure was carried out at $30^{\circ} \mathrm{C}$ and within $2-3 \mathrm{~h}$ after slaughter.

Cumulus-oocyte complexes were cultured in Medium 199 with Earle's salts (Flow Laboratories, Herts, UK), supplemented with $10 \%$ heat-treated fetal calf serum, $1 \mu \mathrm{g} \mathrm{bLH} / \mathrm{ml}, 2 \mu \mathrm{g} \mathrm{bFSH} / \mathrm{ml}$ and $1 \mu \mathrm{g}$ oestradiol- $17 \beta / \mathrm{ml}$. Culture was carried out at $39^{\circ} \mathrm{C}$ in an humidified atmosphere of $5 \% \mathrm{CO}_{2}$ in air and all media were adjusted to pH 7.2 and 280 mosmol.

Radiolabelling of oocyte proteins. After various periods of culture, at least 20 cumulus-oocyte complexes per culture period were either radiolabelled with $\left[{ }^{35} \mathrm{~S}\right]$ methionine or $\left[{ }^{32} \mathrm{P}\right]$ orthophosphate for $3 \mathbf{h}$ at $39^{\circ} \mathrm{C}$. To study protein synthesis, labelling was performed in Medium A, containing $1 \mathrm{mCi} \mathrm{L-}\left[{ }^{35} \mathrm{~S}\right] \mathrm{methionine} / \mathrm{ml}(\mathrm{sp}$. act. $>1000 \mathrm{Ci} /$ mmol; Amersham plc, Amersham, Bucks, UK). Phosphorylation of proteins was investigated by labelling cumulusoocyte complexes with [ ${ }^{32} \mathrm{P}$ ]orthophosphate (carrier free; Amersham plc) at a concentration of $0.5 \mathrm{mCi} / \mathrm{ml}, \mathrm{using}$ bicarbonate-buffered saline, as described by Crosby et al. (1984). Labelled oocytes were denuded of cumulus cells by repeated pipetting and assessed for morphological appearance and nuclear status. Intact and non-degenerate oocytes were lysed individually by adding $20 \mu \mathrm{l} \mathrm{SDS}$-sample buffer (Laemmli, 1970), followed by heating at $100^{\circ} \mathrm{C}$ for $2 \mathrm{~min}$. Samples were stored at $-20^{\circ} \mathrm{C}$ and aliquants of $2 \mu \mathrm{l}$ were used for the determination of the incorporation of radiolabel into TCA-insoluble material.

Assessment of meiotic stage. After culture and radiolabelling, oocytes were denuded of cumulus cells by repeated pipetting and examined under a stereomicroscope for the presence of a germinal vesicle or polar body. This stereomicroscopic assessment was validated in an additional experiment. For this purpose, 222 cumulus-oocyte complexes were cultured for various periods. After denudation, the oocytes were divided into four groups, based on the observation of a germinal vesicle (GV), a polar body (MII) or neither of these (MI), or a degenerating appearance. Subsequently, the oocytes were mounted on slides and fixed in $75 \%$ ethanol $/ 25 \%$ acetic acid for $24 \mathrm{~h}$. The oocytes were stained with $1 \%$ aceto-orcein and the meiotic stage was determined by light microscopy (Table 1). Based on the results, rapid stereomicroscopic assessment sufficed to determine the nuclear status of oocytes in the present labelling experiments.

Table 1. Assessment of nuclear stage of cultured oocytes, before and after orcein staining

\begin{tabular}{lcrccc}
\hline \multirow{2}{*}{$\begin{array}{l}\text { Nuclear status } \\
\text { before staining }\end{array}$} & No. of & \multicolumn{4}{c}{ Nuclear stage after orcein staining } \\
\cline { 3 - 6 } & oocytes & GV (\%) & MI (\%)* & MII (\%) & Degenerate (\%) \\
\hline GV & 51 & $48(94)$ & $3(6)$ & & \\
MI & 96 & $2(2)$ & $94(98)$ & $70(99)$ & $1(1)$ \\
MII & 71 & & & & $3(75)$ \\
Degenerate & 4 & & $1(25)$ & & \\
\hline
\end{tabular}

*Including anaphase I and telophase I oocytes.

Electrophoretic analysis of oocyte proteins. One-dimensional electrophoresis was performed on $8-15 \%$ linear gradient SDS-polyacrylamide gels, according to Laemmli (1970). Fluorography was carried out by treating $\left[{ }^{35}\right.$ S]methionine-containing gels with Amplify ${ }^{\odot}$ (Amersham plc) for $30 \mathrm{~min}$. All gels were dried under vacuum at $80^{\circ} \mathrm{C}$ and subsequently exposed to Kodak-XAR5 film. Mixtures of proteins, with known molecular weights, $M_{\mathrm{r}} 14200$ 205000 (Sigma Chemical Co., St Louis, MO, USA), were run simultaneously as standards, and visualized after electrophoresis by staining with Coomassie blue.

\section{Results}

\section{Protein synthesis during maturation}

To correlate the protein synthesis pattern with the nuclear stage, approximately 200 bovine cumulus-oocyte complexes were radiolabelled with $\left[{ }^{35} \mathrm{~S}\right]$ methionine at different times of culture. 
The protein synthesis patterns were highly reproducible and representative patterns are shown in Fig. 1. Striking changes in the pattern occurred after $4 \mathrm{~h}$ of culture. Oocytes showing such a distinct protein synthesis pattern had undergone GVBD, as no intact germinal vesicle was ever observed in these oocytes. The protein synthesis patterns of 0 and $4 \mathrm{~h}$ exclusively represented oocytes possessing an intact germinal vesicle. Oocytes remaining in the germinal vesicle stage at 8 or even at $12 \mathrm{~h}$ of culture also showed such a pattern. Furthermore, changes were observed after $12 \mathrm{~h}$ of culture, during the transition from metaphase I to metaphase II stage. These changes did not coincide with polar body extrusion, since no polar body was detected in the oocyte cultured for $16 \mathrm{~h}$, i.e. no changes were observed in the protein synthesis patterns after polar body extrusion had occurred (Fig. 1, 20 h).

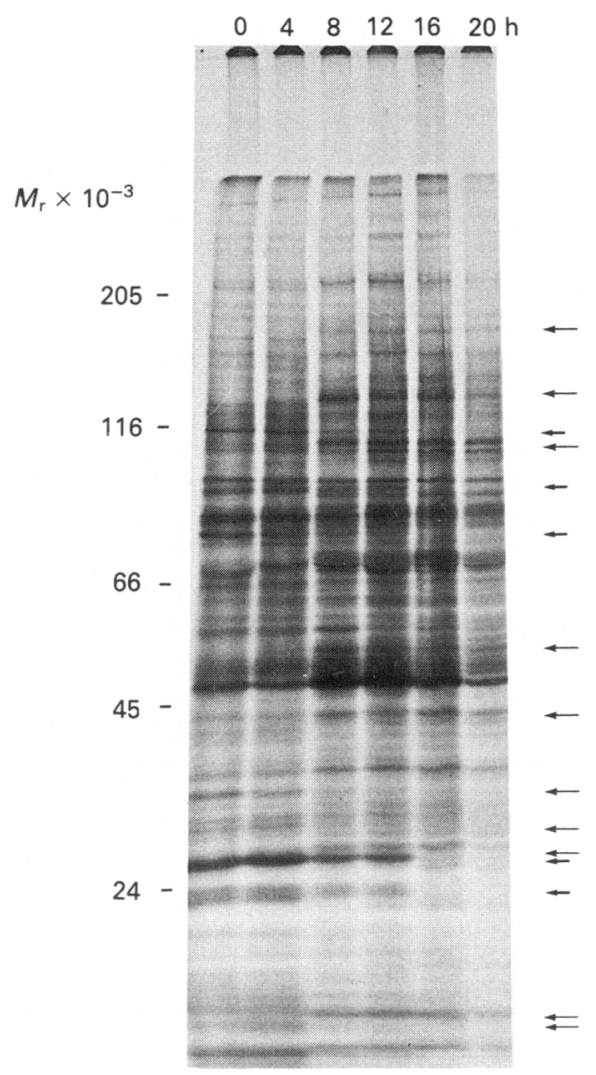

Fig. 1. Protein synthesis patterns after $0,4,8,12,16$ and $20 \mathrm{~h}$ of culture. Each lane is a representative pattern of a group of at least 20 individually labelled oocytes. A germinal vesicle was determined in the 0 - and 4-h cultured oocytes and an extruded first polar body in the $20-\mathrm{h}$ cultured oocyte. In the other oocytes, neither of these were observed. Striking changes in the protein synthesis between 4 and $8 \mathrm{~h}$ of culture, at $M_{\mathrm{r}} 175000,130000,110000,54000,42000$, $33000,30000,28000,15000$ and 14000 (large arrows), and between 12 and $16 \mathrm{~h}$ of culture, at $M_{\mathrm{r}} 116000,95000,80000,26000$ and 22000 (small arrows) are indicated.

\section{Protein phosphorylation during maturation}

Heavily phosphorylated proteins $\left(M_{\mathrm{r}} 19000,24000\right.$ and two between 50000 and 60000$)$ were mainly observed in the phosphorylation patterns before GVBD, when the same 4-h culture intervals were chosen as described above. A sudden increase in labelling was observed, especially after 
$4 \mathrm{~h}$ of culture. However, in these patterns, slight differences in the $M_{\mathrm{r}}$ of the two intensively phosphorylated proteins between 50000 and 60000 were detected. To examine these differences more precisely, about 300 cumulus-oocyte complexes were used to study the protein phosphorylation on a 1-h basis, from 0 up to $9 \mathrm{~h}$ of culture. The sequential phosphorylation patterns (Fig. 2) demonstrate that the phosphoprotein bands between 50000 and 60000 were dominantly displayed in patterns of oocytes cultured for 3 to $7 \mathrm{~h}$ and which were still in the germinal vesicle stage. Thereafter, these bands were less dominant. The phosphoprotein band at $M_{\mathrm{r}} 24000$ was also observed from $3 \mathrm{~h}$ of culture but this band stayed detectable in patterns of oocytes cultured for up to $16 \mathrm{~h}$. The phosphoprotein with apparent $M_{\mathrm{r}} 19000$ was exclusively observed in the patterns of oocytes with an intact germinal vesicle, i.e. mainly from 0 to $7 \mathrm{~h}$. Less obvious changes in the phosphorylation patterns preceding GVBD were found at $M_{\mathrm{r}} 29000$ and 130000 , whereas no changes were observed in the phosphorylation patterns after GVBD.

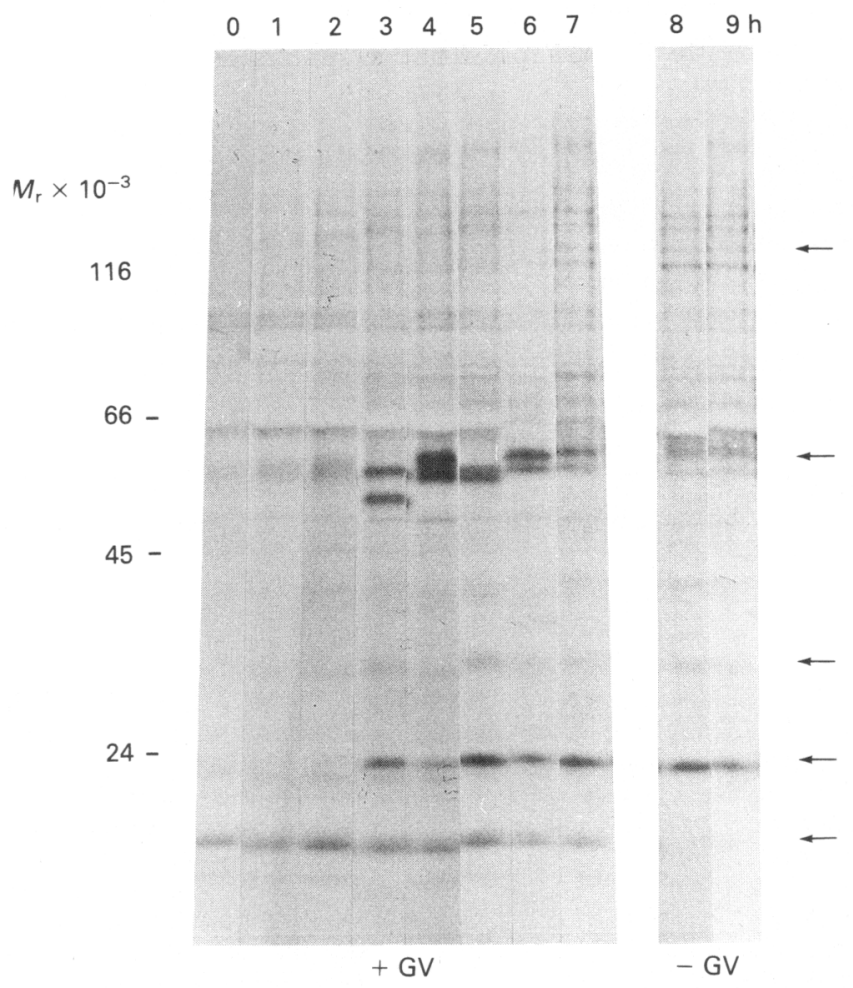

Fig. 2. Protein phosphorylation patterns of bovine oocytes cultured for successive 1-h periods, throughout $9 \mathrm{~h}$ of culture. Each lane is a representative pattern of a group of at least 20 individually labelled oocytes. After radiolabelling, oocytes were assessed for the presence $(+\mathrm{GV})$ or absence $(-\mathrm{GV})$ of a germinal vesicle. The dominant changes at $M_{\mathrm{r}} 19000,24000$ and between 50000 and 60000 , and some minor changes at about 29000 and 130000 , are marked by arrows.

\section{Discussion}

The present study demonstrates that during bovine oocyte maturation changes in protein synthesis exclusively take place after GVBD, whereas extensive phosphorylation of some proteins mainly occurs before GVBD. Despite the necessity of mRNA and protein synthesis to achieve GVBD (Hunter \& Moor, 1987), the synthesis of specific proteins before GVBD, as reported for ovine oocytes (Moor \& Crosby, 1986), was not detected. The most obvious changes are observed shortly 
after GVBD, at the beginning of metaphase I, whereas the disappearance of several polypeptide bands occurs before polar body extrusion. These changes may occur at the end of metaphase I, during the transition to anaphase I/telophase I (Sirard et al., 1989). Previously, extensive changes in protein synthesis after GVBD have also been demonstrated for oocytes of other mammalian species (mouse: Schultz \& Wassarman, 1977; rabbit: Van Blerkom \& McGaughey, 1978; sheep: Moor et al., 1981). In addition, similar changes occur in enucleated oocytes, indicating that the 'reprogramming' of protein synthesis is not dependent on GVBD (Schultz et al., 1978; Sun \& Moor, 1988). However, in this study, oocytes remaining in the germinal vesicle stage exhibited a consistent protein synthesis pattern, even when oocytes were exceptionally retained in the GV stage after 8 or $12 \mathrm{~h}$ of culture. So far, aberrant protein synthesis patterns of GV-containing oocytes are only displayed by degenerate oocytes (Kastrop et al., 1990).

The extensive phosphorylation of some proteins $\left(M_{\mathrm{r}} 24000\right.$ and between 50000 and 60000$)$ is observed from $3 \mathrm{~h}$ after the onset of culture. In addition, a phosphoprotein $M_{\mathrm{r}} 19000$ is exclusively present in patterns of oocytes remaining in the germinal vesicle stage. In spite of the slight molecular weight changes of the two phosphoproteins in the 50000-60000 region, the phosphorylation patterns after a specific culture period are very consistent. The slight differences could be caused by the phosphorylation of different proteins, or by different phosphorylation forms of the same protein(s) (Chen et al., 1989). Our results are in favour of the latter possibility, as only slight differences in the molecular weights were detected and the changes occurred consistently during maturation. The heavily phosphorylated proteins may play a role in the activation of the maturation promoting factor (MPF) or as putative MPF substrates, since in Xenopus oocytes, a tremendous increase in phosphoproteins has been demonstrated to occur shortly before GVBD and in association with the activity of MPF (Maller \& Smith, 1985). The exact function of these phosphoproteins during bovine oocyte maturation is the subject of further study.

This study was supported by grants of the Dutch Program Committee for Agriculture Biotechnology. We thank Mr Th. van Beneden for expert technical assistance; and Dr R. M. Moor for critical reading of the manuscript.

\section{References}

Chen, P.-L., Scully, P., Shew, J.-Y., Wang, J.Y.J. \& Lee, W.-H. (1989) Phosphorylation of the retinoblastoma gene product is modulated during the cell cycle and cellular differentiation. Cell 58, 1193-1198.

Cran, D.G. (1985) Qualitative and quantitative structural changes during pig oocyte maturation. J. Reprod. Fert. 74, 237-245.

Cran, D.G., Moor, R.M. \& Hay, M.F. (1980) Fine structure of the sheep oocyte during antral follicle development. J. Reprod. Fert. 59, 125-132.

Crosby, 1.M., Osborn, J.C. \& Moor, R.M. (1984) Changes in protein phosphorylation during the maturation of mammalian oocytes in vitro. $J$. exp. Zool. 229, 459-466.

De Loos, F., Van Vliet, C., Van Maurik, P. \& Kruip, Th.A.M. (1989) Morphology of immature bovine oocytes. Gamete Res. 24, 197-204.

Dulbecco, R. \& Vogt, M. (1954) Plaque formation and isolation of pure lines with poliomyelitis virus. J. exp. Med. 99, 167-182.

Edwards, R.G. (1965) Maturation in vitro of mouse, sheep, cow, pig, rhesus monkey and human ovarian oocytes. Nature, Lond. 208, 349-351.

Fleming, W.N. \& Saacke, R.G. (1972) Fine structure of the bovine oocyte from the mature Graafian follicle. J. Reprod. Fert. 29, 203-213.
Golbus, M.S. \& Stein, M.P. (1976) Qualitative patterns of protein synthesis in the mouse oocyte. J. exp. Zool. 198, 337-342.

Hunter, A.G. \& Moor, R.M. (1987) Stage-dependent effects of inhibiting ribonucleic acids and protein synthesis on meiotic maturation of bovine oocytes in vitro. J. Dairy Sci. 70, 1646-1651.

Hyttel, P., Xu, K.P., Smith, S. \& Greve, T. (1986) Ultrastructure of in-vitro oocyte maturation in cattle. $J$. Reprod. Fert. 78, 615-625.

Kastrop, P.M.M., Bevers, M.M., Destrée, O.H.J. \& Kruip, Th.A.M. (1990) Analysis of protein synthesis in morphologically classified bovine follicular oocytes before and after maturation in vitro. Molec. Reprod. Devel., in press.

Kruip, T.A.M., Cran, D.G., Van Beneden, T.H. \& Dieleman, S.J. (1983) Structural changes in bovine oocytes during final maturation in vivo. Gamete Res. $8,29-47$.

Laemmli, U.K. (1970) Cleavage of structural proteins during the assembly of the head of bacteriophage T4. Nature, Lond. 227, 680685.

Maller, J.L. \& Smith, D.S. (1985) Two-dimensional polyacrylamide gel analysis of changes in protein phosphorylation during maturation of Xenopus oocytes. Devl Biol. 109, 150-156. 
McGaughey, R.W. \& Van Blerkom, J. (1977) Patterns of polypeptide synthesis of porcine oocytes during maturation in vitro. Devl Biol. 56, 241-254.

Moor, R.M. \& Crosby, I.M. (1986) Protein requirements for germinal vesicle breakdown in ovine oocytes. $J$. Embryol. exp. Morph. 94, 207-220.

Moor, R.M. \& Trounson, A.O. (1977) Hormonal and follicular factors affecting maturation of sheep oocytes in vitro and their subsequent developmental capacity. J. Reprod. Fert. 49, 101-109.

Moor, R.M., Osborn, J.C., Cran, D.G. \& Walters, D.E. (1981) Selective effect of gonadotrophins on cell coupling, nuclear maturation and protein synthesis in mammalian oocytes. J. Embryol. exp. Morph. 61, $347-365$.

Pincus, G. \& Enzmann, E.V. (1935) The comparative behavior of mammalian eggs in vivo and in vitro. I. The activation of ovarian eggs. J. exp. Med. 62, $665-675$.

Schultz, R.M. \& Wassarman, P.M. (1977) Biochemical studies of mammalian oogenesis: protein synthesis during oocyte growth and meiotic maturation in the mouse. J. Cell Sci. 24, 167-194.

Schultz, R.M., Letourneau, G.E. \& Wassarman, P.M. (1978) Meiotic maturation of mouse oocytes in vitro: protein synthesis in nucleate and enucleate oocyte fragments. J. Cell Sci. 30, 251-264.

Sirard, M.A., Florman, H.M., Leibfried-Rutledge, M.L., Barnes, F.L., Sims, M.L. \& First, N.L. (1989) Timing of nuclear progression and protein synthesis necessary for meiotic maturation of bovine oocytes. Biol. Reprod. 40, 1257-1263.

Sun, F.Z. \& Moor, R.M. (1988) Nuclear cytoplasm interactions during ovine oocyte maturation. J. Reprod. Fert., Abstr. Ser. 1, 9, abstr.

Szöllösi, D. (1972) Changes of some cell organelles during oogenesis in mammals. In Oogenesis, pp. 47-64. Eds J. D. Biggers \& A. W. Schuetz. University Park Press, Baltimore.

Van Blerkom, J. \& McGaughey, R.W. (1978) Molecular differentiation of the rabbit ovum. 1. During oocyte maturation in vivo and in vitro. Devl Biol. 63, $139-150$.

Warnes, G.M., Moor, R.M. \& Johnson, M.H. (1977) Changes in protein synthesis during maturation of sheep oocytes in vivo and in vitro. J. Reprod. Fert. 49, $331-335$.

Received 7 February 1990 